\title{
Extraction of Mastitis Pathogen DNA from Sample Collecting Cards: Practical Consequences
}

\author{
Durel $\mathrm{L}^{{ }^{*}}$, Benoit $\mathrm{F}^{2}$, Treilles $\mathrm{M}^{3}$ and Farre $\mathrm{M}^{4}$ \\ ${ }^{1}$ Virbac, $13^{\text {ème }}$ rue LID, 06511, Carros Cedex, France \\ ${ }^{2}$ LABEO Manche 50100 SAINT-LO, France \\ ${ }^{3}$ LASAT 79000 NIORT, France \\ ${ }^{4}$ SEGES 8200 ÅRHUS, Denmark
}

*Corresponding author: Durel L, VIRBAC, $13^{\text {ème }}$ rue LID, 06511 CARROS Cedex, France, Tel: +33 492087882,

E-mail: luc.durel@virbac.com

Citation: Durel L, Benoit F, Treilles M, Farre M (2015) Extraction of Mastitis Pathogen DNA from Sample Collecting Cards: Practical Consequences. J Vet Sci Anim Husb 3(2): 202. doi: 10.15744/2348-9790.1.602

Received Date: February 20, 2015 Accepted Date: April 13, 2015 Published Date: April 16, 2015

\begin{abstract}
Shipment of liquid milk samples for bacteriological examination is a limitation to large scale epidemiological studies. Sampling bulk tank milk (BTM) with sample collection cards (Whatman ${ }^{\mathrm{TM}} \mathrm{FTA}^{\mathrm{TM}}$ MiniCard) was identified as an interesting procedure to ease sample collection and shipment. First, an extraction protocol was developed in order to ensure detection of S. aureus, S. agalactiae and M. bovis in BTM samples at concentrations $\geq 10^{4} \mathrm{CFU} \cdot \mathrm{mL}^{-1}$. In a second step, $10 \mathrm{BTM}$ samples (30 tests) were assayed directly from liquid milk, or from collecting cards impregnated with milk. Without respect to the $\mathrm{Ct}$ value, all positive signals $(\mathrm{Ct} \neq 0)$ were considered as positive results. Both tests yielded same positive or negative results for 10 out of 11 , and 18 out of 19 of milk samples tested respectively. Finally, from a pilot epidemiological study carried out in selected dairy operations in Europe, current herd-prevalence of S. agalactiae, S. aureus and M. bovis in Europe was estimated to be 8.9, 32.9 and 1.3\% respectively, S. agalactiae and M. bovis being identified in some countries only. This study confirms that $S$. agalactiae is more frequently identified in BTM displaying acceptable SCC levels, than in high SCC BTM. Storage and shipment of BTM samples with collecting cards do not impair results of PCR testing. This technique allows cheaper and easier BTM bacteriology testing and would be recommended for large scale epidemiological surveys, or routine diagnostic-based dry cow therapy veterinary prescription.
\end{abstract}

Keywords: Mastitis; Streptococcus agalactiae; PCR; Sample collection card; Bulk tank milk sampling; Bacteriology

Abbreviations: BTM: Bulk Tank Milk: BTMSCC: BTM Somatic Cell Count; CT: Cycle threshold; PCR: Polymerase chain reaction; LOD: Limit of detection

\section{Introduction}

Bulk tank milk (BTM) testing is a routine procedure for assessing milk quality, milking hygiene and herd-level health problems in the dairy industry. Bulk tank milk (BTM analysis sounds particularly useful for assessing udder health status [1-3].

As for many biological samples collected from animals, attention must be paid by the practitioner when shipping milk from the farm to the laboratory. According to international standards (document WHO/HSE/GCR/2012.12) [4], biological secreta, collected directly from animals, being transported for purposes such as research, diagnosis, investigational activities, disease treatment and prevention are considered as patient specimens (animal). Since there is only minimal likelihood that pathogens are present, and based on the informed professional judgement of the veterinarian with respect to the individual and epizootic conditions, these specimens may be regarded as 'Exempt Animal Specimens'. Nevertheless, shipment of exempt specimens needs a triple packaging. Basically, an individual sample is enclosed in a watertight, leak-proof receptacle (container with screw cap). Then a second, durable, watertight, leak-proof packaging must enclose the primary receptacle(s) (a zip lock plastic pouch is appropriate). Finally, and not talking about cold packs, the secondary packaging(s) is/are placed in an outer shipping packaging designed to protect its contents from physical damage while in transit (cardboard box). Packaging and shipment fees may finally exceed the cost of analysis itself.

Sample collection cards may offer a new opportunity for transportation of milk samples. It could be assumed that BTM is a foodstuff that may be fed to animals and humans without a significant risk of infection. Or, as transport regulations specifically consider dried blood spots, the same provisions could eventually apply to dried milk spots. Finally, quality sample collection cards lyse cells on contact, denature proteins, and protect DNA from degradation. Therefore, specimens collected on collection cards would be considered as free of live pathogenic germs and would not be subjected to any of transport requirements for dangerous goods and may be shipped by regular mail. 
Whereas detection of mastitis pathogens by PCR from liquid milk has been carefully substantiated [5] and is now routinely used for large scale udder health surveys [6], extraction from filter paper has not been extensively tested [7,8] and some details of the technique deserve to be improved.

Combining dried milk spots (DMS) collected on collection cards and PCR detection would certainly provide a powerful tool to facilitate submission of samples and to implement cheap epidemiological studies. The aim of this article is to present some improvements in DNA extraction from filter paper. The combination filter paper/PCR was also evaluated in a large scale European test and preliminary results are presented afterwards.

\section{Materials and Methods}

The combination of Whatman ${ }^{\mathrm{TM}} \mathrm{FTA}^{\mathrm{TM}}$ MiniCards (GE Healthcare Bio-Sciences, Pittsburgh, PA, USA) for milk sampling and PathoProof ${ }^{\mathrm{TM}}$ Mastitis Major 3 Assays (Thermo Fisher Scientific, Waltham, MA, USA) for PCR testing, was tested in a three step process. This kit targets Staphylococcus aureus, Streptococcus agalactiae and Mycoplasma bovis as the main contagious mastitis pathogens in the cow. S. agalactiae and M. bovis when found in BTM samples, are from intra-mammary origin and are very likely to indicate intra-mammary infections due to this pathogens. S. aureus is a well-known agent of contagious mastitis, but it may be from intra-mammary origin (infection) as well as extra-mammary origin (teat skin, milker's hands). It was assumed that $S$. aureus would be frequently observed in BTM samples, without respect to its epidemiological importance. Therefore, $S$. aureus DNA detection was used as a help for the interpretation of results, excessively frequent negative results indicating a poor analytical sensitivity.

\section{First Step: Limit of detection assessment}

Routine Bactoscan (or similar tests) indicates that BTM bacterial counts generally range from $5.10^{3}$ to $10^{5}$ CFU of aerobic mesophilic organisms per mL. Therefore, in $50 \mu \mathrm{L}$ of milk (1-2 drops), only 250 to 5000 organisms may be collected. The ability of a commercial RT-PCR assay to detect a given bacteria from such a limited amount of milk deserved to be tested. Tests were made with strains of S. aureus, S. agalactiae and M. bovis selected from the laboratory repository (LABEO Manche, Saint-Lô, France).

Appropriate stock solutions (D1) were obtained by mixing $100 \mu \mathrm{L}$ of a $0.5 \mathrm{McF}$ arland solution of S. aureus or S. agalactiae into 900 $\mu \mathrm{L}$ of sterile milk. For M. bovis, $100 \mu \mathrm{L}$ of a 72-hours old broth was used. Then logarithmic serial dilutions of stock solutions were performed (D2 to D7).

For every single diluted solution, the bacterial load was assessed by plating $50 \mu \mathrm{L}$ on blood agar and incubating for $48 \mathrm{~h}$. At the same time, a collection card sampling area was impregnated with $50 \mu \mathrm{L}$. When the sampling areas looked dry ( $3 \mathrm{~h}$, room temperature), 1 or 3 circular $(\varnothing 1.2 \mathrm{~mm})$ punches were collected from the sampling areas (punch-in method), and then processed for DNA extraction and PCR testing. Amplification runs were performed by a STRATAGENE MX3000P thermocycler. With respect to supplier's instructions, 45 amplification cycles were performed. All samples with a positive signal and Ct<45 were declared positive.

Results from bacterial culture on one hand $\left(10^{\mathrm{n}} \mathrm{CFU} / \mathrm{mL}\right)$, and PCR (+ or -) on the other hand were finally compared. The limit of detection (LOD) was the lowest bacterial count associated with a positive PCR result.

\section{Second Step: Collection card and fresh milk comparison}

Due to the solid nature of FTA cards, the DNA extraction phase from fresh milk or from cards differs. According to manufacturer's recommendation (PathoProof ${ }^{\mathrm{TM}}$ Mastitis Major 3 Assays), $350 \mu \mathrm{L}$ of fresh milk must be processed in the extraction phase. Volume of milk on tiny punches of a FTA card is not known and only a few pieces of the device can be added to the lysis solution. From this step, the extraction kit of the commercial mastitis assay can be used. Amplification of the purified DNA does not differ between the two methods. Since the objective of this study is to compare PCR testing on FTA card impregnated with milk and fresh milk, both fresh milk sample and FTA card from the same BTM collected on the same day has to be carried out. DNA detection on fresh milk may be considered as the gold standard and this method has already been validated [5]. Therefore not any milk culture has been performed.

Denmark is one of the European countries where control of $S$. agalactiae relies on a public policy. Therefore, all bulk milk tanks are tested for this pathogen on a periodical basis and the true herd prevalence is well known [6]. Volunteer dairy operations where $S$. agalactiae had been observed in the recent past were enlisted for a single BTM sampling. On the same day, a sample of fresh liquid BTM was sent to a local laboratory (EUROFINS, Vejen, Denmark) whereas a milk-impregnated FTA card was sent to the French laboratory by regular mail. Samples were assayed for the three pathogens with the same commercial kit. Cycle threshold (Ct) values were compared. Samples with $\mathrm{Ct}<45$ were declared positive.

\section{Third Step: On-field study}

Whatman ${ }^{\mathrm{TM}} \mathrm{FTA}^{\mathrm{TM}}$ MiniCards (2 sampling areas) and pre-paid/pre-printed envelopes were sent to the local technical staff of a major veterinary pharmaceutical company (VIRBAC, France) in several European countries (Austria, Belgium, Denmark, France, Germany, Greece, Hungary, Italy, Ireland, Portugal, Spain, Switzerland, The Netherlands, United Kingdom). They were requested to contact some local field veterinarians and to propose them to collect samples of milk in herds with a known history of BTM 
SCC $>300.000$ cells $/ \mathrm{mL}$. The veterinarians were instructed to work cleanly. They were advised to pick up milk from a full or nearly full tank in order to facilitate collection; when appropriate, mixers were in operation and the bulk milk was well homogenized. The vets were also specially instructed not to touch the sampling areas on the cards, nor to place the paper into their mouth while manipulating the milk. Milk was taken directly into a disposable pipette from the bulk milk in the tank (in large facilities, milk was occasionally first collected with a ladle) and 2 or $3 \mathrm{~mL}$ were applied onto the card, until saturation. Collecting cards were dried on farm. A form was also provided in order to collect a minimal dataset from visited farms, including farm owner and veterinarian identities and addresses, number of lactating cows, estimated volume of milk at the time the sample was collected, last three monthly official BTM SCC. After the collecting card was placed into a plastic sealable pouch, the card and form were sent in the same envelope by regular mail. The total weight of the shipment was approximately $20 \mathrm{~g}$. No liquid milk samples were supposed to be sent for complementary analysis.

\section{Results}

\section{LOD}

The results of milk culture and PCR testing are presented in Table 1. For the 3 bacteria, the very last dilution giving a reproducible positive result with $\mathrm{Ct}$ lower than 40 was the dilution 4 .

\begin{tabular}{|c|c|c|c|c|c|}
\hline Strain & Dilution & $\mathrm{Ct}$ & Result & $\begin{array}{l}\text { cfu for } 50 \mu \mathrm{l} \\
\text { inoculum }\end{array}$ & $\mathrm{cfu} / \mathrm{mL}$ \\
\hline S. aureus & 3 & 37.21 & + & 1000 & $2.0 \times 10^{4}$ \\
\hline S. aureus & 4 & 38.51 & + & \multirow{2}{*}{500} & \multirow{2}{*}{$1.0 \times 10^{4}$} \\
\hline S. aureus & 4 & 39.15 & + & & \\
\hline S. aureus & 5 & no Ct & - & \multirow{2}{*}{80} & \multirow{2}{*}{$1.6 \times 10^{3}$} \\
\hline S. aureus & 5 & 37.90 & + & & \\
\hline S. aureus & 6 & no Ct & - & \multirow{2}{*}{11} & \multirow{2}{*}{$2.2 \times 10^{2}$} \\
\hline S. aureus & 6 & 37.59 & + & & \\
\hline S. aureus & 7 & 36.6 & + & \multirow{2}{*}{1} & \multirow{2}{*}{$2.0 \times 10^{1}$} \\
\hline S. aureus & 7 & 38.79 & + & & \\
\hline Str. agalactiae & 3 & 29.03 & + & 1000 & $2.0 \times 10^{4}$ \\
\hline Str. agalactiae & 4 & 37.02 & + & \multirow{2}{*}{200} & \multirow{2}{*}{$4.0 \times 10^{3}$} \\
\hline Str. agalactiae & 4 & 37.22 & + & & \\
\hline Str. agalactiae & 5 & 37.41 & + & \multirow{2}{*}{50} & \multirow{2}{*}{$1.0 \times 10^{3}$} \\
\hline Str. agalactiae & 5 & no $\mathrm{Ct}$ & - & & \\
\hline Str.agalactiae & $>5$ & no Ct & - & 5 & $1.0 \times 10^{2}$ \\
\hline M. bovis & 2 & 32.30 & + & 720 & $1.4 \times 10^{4}$ \\
\hline M. bovis & 4 & 37.02 & + & 122 & $2.4 \times 10^{3}$ \\
\hline M. bovis & 5 & no Ct & - & 26 & $5.2 \times 10^{2}$ \\
\hline M. bovis & 6 & no Ct & - & 0 & - \\
\hline
\end{tabular}

Table 1: Assessment of the Limit of Detection (LOD, cfu/mL) of the PCR assay. The last dilution that yields positive PCR results only was regarded as the LOD for the targeted species. Enumeration of bacterial colonies was then performed from a $50 \mu \mathrm{L}$ inoculum and converted in $\mathrm{cfu} / \mathrm{mL}$. Only $\mathrm{Ct}<45$ were considered

The LOD of the overall method was estimated to range from 100 to $500 \mathrm{cfu}$ per inoculum of $50 \mu \mathrm{l}$, i.e. $2 \times 10^{3} \mathrm{cfu} / \mathrm{ml}$ (M. bovis), $1 \times 10^{4} \mathrm{cfu} / \mathrm{ml}$ (S. aureus) and $4 \times 10^{3} \mathrm{cfu} / \mathrm{ml}$ (S. agalactiae).

The use of 3 punches instead of 1 did not significantly improve the LOD for S. agalactiae, mainly because of the extra volume of elution solution.

\section{Ct values correlation}

Ten fresh and 10 dried milk samples were processed with the same commercial PCR kit, for the 3 pathogenic bacteria, leading to 30 couples of comparable data. The results are plotted in Table 2. With respect to within-laboratory differences, Ct values were found to be very similar in most of the tests ( 24 out of 30 tests). Only 2 dramatic discordances were pointed out for S. agalactiae. M. bovis was absent in all samples. Two samples were positive for 2 pathogens with agreement between both techniques. On one hand, only considering $\mathrm{Ct}<45$ samples, on 11 positive results with fresh milk, 10 similar results were found with milk stored on cards. On the other hand, on 19 negative samples $(\mathrm{Ct}=0), 18$ were correctly assessed with the test on collecting cards. Therefore, the estimated sensitivity and specificity are 0.91 and 0.95 respectively. 


\begin{tabular}{|c|c|c|c|c|c|c|}
\hline & \multicolumn{7}{|c|}{ Ct value } \\
\hline & \multicolumn{2}{|c|}{ Staphylococcus aureus } & \multicolumn{2}{|c|}{ Streptococcus agalactiae } & \multicolumn{2}{|c|}{ Mycoplasma bovis } \\
\hline Herd/tank & Lab\#1 & Lab\#2 & Lab\#1 & Lab\#2 & Lab\#1 & Lab\#2 \\
\hline 69943 & 35 & 35 & no Ct & no Ct & no Ct & no Ct \\
\hline MF3 & 33 & 33 & no Ct & no Ct & no Ct & no Ct \\
\hline LH3 & 29 & 29 & 35 & no Ct & no Ct & no Ct \\
\hline MF1 & no Ct & no Ct & no Ct & no Ct & no Ct & no Ct \\
\hline $11 \varnothing 5$ & no Ct & no Ct & no Ct & no Ct & no Ct & no Ct \\
\hline MF2 & 34 & 34 & no Ct & no Ct & no Ct & no Ct \\
\hline MF4 & 33 & 34 & no Ct & no Ct & no Ct & no Ct \\
\hline LH1 & 33 & 36 & no Ct & 25 & no Ct & no Ct \\
\hline LH2 & 33 & 33 & 31 & 33 & no Ct & no Ct \\
\hline $12 \varnothing$ & 30 & 33 & 38 & 32 & no Ct & no Ct \\
\hline
\end{tabular}

Table 2: Ct values of PCR (PathoProof) performed from milk collected and dried on card (Whatman FTA MiniCard) (results from Lab\#1) or liquid fresh milk (results from Lab\#2) collected in 10 Danish dairy herds, for the three targeted species. Only $\mathrm{Ct}<45$ were considered

\section{Field Survey results}

One-hundred and forty sample collecting cards were sent to corresponding veterinarians in 14 European countries. Over a 12 month period, 79 samples were sent back to the laboratory. Samples came from 10 countries, mainly Belgium, Denmark, Hungary, Spain and Poland (57/79). Only 75 samples were provided with sufficient BTMSCC data.

The samples were collected in farms for which the average dairy herd size was 345 cows (13-4.200). The average volume of bulk milk was estimated to be $7300 \mathrm{~L}$ (200-43000). Bulk tanks as large as $26000 \mathrm{~L}$ have been found positive. At least one pathogen was identified in $39.2 \%$ of submitted samples. S. aureus, S. agalactiae and M. bovis were found in 32.9, 8.9 and 1.3\% of BTM samples.

From available data, average BTMSCC was about $270.10^{3}$ cells $/ \mathrm{mL}$ at the time of sampling as well as in the 3 former months. For unreported reasons, $45.3 \%$ of samples were collected in operations where the BTMSCC was consistently below $300.10^{3}$ cells $/ \mathrm{mL}$. Amazingly, these unexpected samples account for $43.3 \%$ of positive results; 42.3 and $71.4 \%$ of SCC $<300.10^{3}$ cells $/ \mathrm{mL} \mathrm{BTM} \mathrm{were}$ positive for $S$. aureus or S. agalactiae respectively (Table 3).

\begin{tabular}{|c|c|c|c|c|c|c|c|}
\hline & & \multicolumn{6}{|c|}{ BTMSCC classes $\left(\times 10^{3}\right.$ cells $\left./ \mathrm{mL}\right)$} \\
\hline & $<100$ & $100-200$ & 200-300 & $300-400$ & $400-500$ & $>500$ & Total \\
\hline $\mathrm{n}$ & 3 & 19 & 12 & 27 & 9 & 5 & 75 \\
\hline \multirow{2}{*}{$\begin{array}{l}\text { Positive samples } \\
\quad(\mathrm{Ct}<45)\end{array}$} & 1 & 6 & 6 & 10 & 4 & 3 & 32 \\
\hline & \multicolumn{3}{|c|}{$13 / 30(43.3 \%)$} & \multicolumn{3}{|c|}{$17 / 30(56.7 \%)$} & 30 \\
\hline \multirow{2}{*}{ S. aureus +} & 1 & 5 & 5 & 10 & 3 & 2 & \multirow{2}{*}{26} \\
\hline & \multicolumn{3}{|c|}{$11 / 26(42.3 \%)$} & \multicolumn{3}{|c|}{$15 / 26(57.7 \%)$} & \\
\hline \multirow{2}{*}{ S. agalactiae + } & 0 & 1 & 4 & 1 & 0 & 1 & \multirow{2}{*}{7} \\
\hline & & /7 (71.4\%) & & & $/ 7(28.6 \%$ & & \\
\hline \multirow{2}{*}{ M. bovis +} & 0 & 0 & 0 & 0 & 1 & 0 & \multirow{2}{*}{1} \\
\hline & \multicolumn{3}{|c|}{ 0/1 (0\%) } & \multicolumn{3}{|c|}{$1 / 1(100 \%)$} & \\
\hline
\end{tabular}

Table 3: Number of samples available for interpretation (n), stratified by BTMSCC classes. 75 samples were available of which 30 yielded a positive result $(\mathrm{Ct}<45)$. Number of positive samples as well as samples found positive for S. aureus, S. agalactiae or M. bovis are detailed per BTMSCC class. On the second row of each category, results have been gathered according to the 300.000 cells $/ \mathrm{mL}$ cut-off. Number of positive results out of the total of the category and \% (in brackets) are indicated

\section{Discussion}

Our study confirms that DNA from bovine mastitis pathogens may be recovered from dried BTM samples stored on sample collecting cards. The improved extraction protocol described in this paper allows detection of the three targeted pathogenic organisms at initial concentrations of $10^{3} \mathrm{cfu} / \mathrm{mL}$ or higher with a commercial PCR kit.

Amplification of DNA fragments by PCR from milk has already been successfully investigated by many authors [5,9-13]. PCR assays on raw milk face two difficulties, 1) the PCR inhibition activity of milk components 2) the low concentration of bacteria in BTM. Reaction conditions have long been recognized as important to sensitive and reproducible amplification. Milk components may block DNA and shield it from access by polymerase. The $\mathrm{Ca}^{2+}$ ions in milk may be a cause of its inhibitory properties [14]. In commercial dairies, total bacterial counts (BC) of shipped milk usually range from $10^{3}$ to $10^{5} \mathrm{cfu} / \mathrm{mL}$. Although BTM cultures 
have been recommended for identification of herds at risk for contagious mastitis $[1,15,16]$, enumeration of specific mammary pathogens is not systematically performed; when available BC can be as low as $10^{3} \mathrm{cfu} / \mathrm{mL}$ [2]. An European study found that high BTMSCC herds $\left(467-909 \times 10^{3}\right.$ cells $\left./ \mathrm{mL}\right)$ harboured $S$. aureus and mastitis streptococci at enumerable levels of $3 \times 10^{2}$ and $1.5 \times 10^{3}$ $\mathrm{cfu} / \mathrm{mL}$ respectively [17]. The low specific bacterial counts may impair the interest of this technique, yielding a high rate of false negative results. In studies performed in the early 2000's, where DNA was extracted from liquid milk, S. aureus could be detected at a concentration of $5 \times 10^{3} \mathrm{cfu} / \mathrm{mL}$ [12] and S. agalactiae at a concentration of $10^{3}$ to $10^{4} \mathrm{cfu} / \mathrm{mL}$ [18]; an enrichment process was needed in order to lower the limit of detection (LOD). However, things are improving fast and LODs for mammary pathogens in milk by PCR without enrichment are as low as $40 \mathrm{cfu} / \mathrm{mL}$ for $S$. aureus [19], 2x10 $0^{2} \mathrm{cfu} / \mathrm{mL}$ for S. agalactiae [7], and 10 cfu/mL for M. bovis [15]. In the present study S. aureus was inconsistently detected in some samples at concentrations close to $20 \mathrm{cfu} / \mathrm{mL}$.

Lampel et al. (2000) [20] demonstrated that various aliquots from concentrated food washes subsequently spotted onto sample collecting cards and assayed by PCR, yielded consistently positive results and LOD similar to those observed with pure-culture dilutions. A few studies have investigated DNA extraction from milk spotted onto cards $[7,8,21]$. DNA identification is supposed to be carried out with very small parts of the card (2 punches of $\varnothing 1.2 \mathrm{~mm}$ ), and quantification of the bacterial load in the initial milk sample with such a limited matrix is not feasible. Therefore processing larger pieces of the card (5 mm or the whole inoculation area, with larger volume of incubation buffer has been proposed. These adaptations allow the use of larger amounts of milk, up to $250 \mu \mathrm{L}$. LODs for these techniques would be $2 \times 10^{2} \mathrm{cfu} / \mathrm{mL}$ for S. agalactiae, 10 to $10^{2}$ for S. aureus, $10^{2}$ to $10^{3}$ for E. coli and CNS [7].

In the present study, the proposed technique was compared to DNA extraction from liquid milk, as recommended by the manufacturer. Specificity and sensitivity were estimated on a small batch of samples. They are however quite close to those calculated by Wu et al. (2008)[7].

Fields veterinarians involved in this project volunteered to collect BTM samples and they didn't get any incentive nor compensation for this work. Therefore, the number of samples is limited but sufficient enough to demonstrate the feasibility of the proposed technique. Veterinarians involved in the field study were requested to sample elevated SCC bulk tanks. Nevertheless, BTMSCC were as low as $70 \times 10^{3}$ cells $/ \mathrm{mL}$ at the time of sampling. The provisions of the EU Hygiene Package on milk quality are now implemented all over the European Union. Therefore, herds with official long-lasting elevated BTMSCC are rare. It is hypothesized that veterinary surgeons did use BTMSCC to make their decision, but they also used other unreported criteria in order to identify problem herds, i.e. herds with elevated SCC cows or known history of mastitis. With DNA extracted from FTA cards, Ct values are generally high (data not reported) with $8 \mathrm{Ct}$ values out of 11 exceeding 33. A high Ct values indicates a low concentration of pathogenic DNA. As lack of sensitivity was one of the major concerns of the proposed technique, the only limit to the DNA replication process has been sat to 45 cycles, according to supplier's guidance. Results were thus positive $(\mathrm{Ct}<45)$ or negative (no Ct). Consequently, many BTM samples from herds with acceptable BTMSCC $(<300.000$ cells $/ \mathrm{mL})$ were found to be contaminated by S. agalactiae, and less significantly by $S$. aureus. In a recent report, Katholm et al. (2012) demonstrated the correlation between low Ct values and high BTMSCC. They were also able to set various breakpoints for correlation with respect to the pathogen identified in the milk. In this study, Danish authors performed PCR test on fresh liquid milk and they processed $350 \mu \mathrm{L}$ of milk. Due to the limited number of BTM samples tested and more likely to the tiny amount of milk processed, the present study did not yield similar breakpoints. It is however generally admitted that $S$. agalactiae is associated with a marked elevation in milk SCC and can be associated with very high bacterial counts [22]. This study shows that major contagious pathogens may be isolated in milk samples from BTM with low SCC. This observation is in agreement with results reported by others [23,24]. S. agalactiae may be discovered in BTM considered to be perfectly acceptable, with no observable inflammatory response. Therefore, this pathogen remains a potential threat, and lack of compliance in preventive control measures could lead to a rapid re-emergence of major Gram positive intra-mammary infections.

In recent BTM surveys, PCR has been used for estimating the actual herd prevalence of several contagious mastitis pathogens. In Canada, a study on 117 dairy herds found that the respective prevalence of S. aureus, S. agalactiae and M. bovis was 84.6, 7.7 and 2.6\% [15]. Danish investigations yielded similar results with 91 and 7\% for S. aureus and S. agalactiae respectively [6]. According to Belgian studies, the M. bovis dairy herd prevalence was 1.5\% of 200 herds sampled [25]. In the Brandenburg area (Germany), herd prevalence of S. agalactiae was found to be $29 \%$ [26]; such a herd prevalence has also been reported in UK [24]. Whereas the S. agalactiae and $M$. bovis herd prevalence found in the present study were similar to already published results, the $S$. aureus prevalence was much lower. S. aureus is not a specific mammary pathogen and as multiple sources exist, it should be detectable in a majority of samples. A lack of analytical sensitivity is therefore suspected and the proposed technique could be improved.

Analyse cost and turn over time to get results are very similar for fresh milk or milk spotted on a FTA card. A Whatman ${ }^{\mathrm{TM}}$ FTA $^{\mathrm{TM}}$ MiniCards is much more expensive (6 to $7 €$ ) than a $30 \mathrm{~mL}$ screwed cap plastic jar. Assuming that milk samples for PCR testing only may be sent at room temperature (not recommended), standard 3 layers shipment kits suitable for Category B UN3373 can be used. They are as expensive ( 7 to $8 €$ ) as FTA cards. Several FTA cards can be sent by regular mail all over Europe at very low price (1.5 $€$ ) whereas international shipment costs of parcels range from 13 (parcels delivered within the next 2 to 4 days) to 50 Euros (following working day delivery). Consequently, milk sampling with FTA cards allows significant savings for epidemiological studies. 


\section{Conclusion}

Extraction from liquid milk and from sample collecting cards showed similar results. The use of cards makes bulk tank milk sampling and shipment very easy and cheap, while results do not seem to be impaired by the transportation media. Identification of major contagious pathogens by such a technique could certainly facilitate large scale epidemiological surveys and be supportive of milk quality improvement policies.

\section{Acknowledgement}

The authors gratefully acknowledge the staff of the GDS du Calvados, as well as colleagues, veterinarians and farmers who generously contributed to this study. This study has been funded by VIRBAC S.A. (France).

\section{References}

1. Godkin MA, Leslie KE (1993) Culture of bulk tank milk as a mastitis screening test: A brief review. Can Vet J 34:601-5.

2. Rysanek D, Zouharova M, Babak V (2009) Monitoring major mastitis pathogens at the population level based on examination of bulk tank milk samples. J Dairy Res 76: 117-23.

3. Jayarao BM, Wolfgang DR (2003) Bulk-tank milk analysis. A useful tool for improving milk quality and herd udder health. Vet Clin North Am Food Anim Pract 19: 75-92.

4. WHO/HSE/GCR/2012.12 Guidance on regulations for the Transport of Infectious Substances 2013-2014.

5. Koskinen MT, Holopainen J, Pyörälä S, Bredbacka P, Pitkälä A, et al. (2009) Analytical specificity and sensitivity of a real time polymerase chain reaction assay for the identification of bovine mastitis pathogens. J Dairy Sci 92: 952-9.

6. Katholm J, Bennedsgaard TW, Koskinen MT, Rattenborg E (2012) Quality of bulk tank milk samples from Danish dairy herds based on real-time polymerase chain reaction identification of mastitis pathogens. J Dairy Sci 95: 5702-8.

7. Wu J, Liu Y, Hu S, Zhou J (2008) Development of a Rapid PCR Test for Identification of Streptococcus agalactiae in Milk Samples Collected on Filter Paper Disks. Asian-Australian J Anim Sci 21: 124-30.

8. Valls L, Lazaro M, Jubert A, et al. (2010) A new methodology for the detection and quantification of pathogenic bacteria in bovine bulk tank milk. Proc. 1st EAVLD. Lelystad.

9. Cremonesi P, Castiglioni B, Malferrari G, Biunno I, Vimercati C, et al. (2006) Technical note: Improved method for rapid DNA extraction of mastitis pathogens directly from milk. J Dairy Sci 89: 163-9.

10. Gillespie BE, Oliver SP (2005) Simultaneous detection of mastitis pathogens, Staphylococcus aureus, Streptococcus uberis, and Streptococcus agalactiae by multiplex real-time polymerase chain reaction. J Dairy Sci 88: 3510-8.

11. Phuektes P, Mansell PD, Browning GF (2001) Multiplex polymerase chain reaction assay for simultaneous detection of Staphylococcus aureus and streptococcal causes of bovine mastitis. J Dairy Sci 84: 1140-8.

12. Riffon R, Sayasith K, Khalil H, Dubreuil P, Drolet M, et al. (2001) Development of a rapid and sensitive test for identification of major pathogens in bovine mastitis by PCR. J Clin Microbiol 39: 2584-9.

13. Forsman P, Tilsala-Timisjärvi A, Alatossava T (1997) Identification of staphylococcal and streptococcal causes of bovine mastitis using $16 \mathrm{~S}-23 \mathrm{~S}$ rRNA spacer regions. Microbiology 143: 3491-3500.

14. Wilson IG (1997) Inhibition and facilitation of nucleic acid amplification. Appl Environ Microbiol 63: 3741- 51.

15. Francoz D, Bergeron L, Nadeau M, Beauchamp G (2012) Prevalence of contagious mastitis pathogens in bulk tank milk in Québec. Can Vet J 53: 1071-8.

16. Frank NA, Pounden WD (1963) Mastitis tests of bulk tank milk and quarter samples from the same dairy herds. J Am Vet Med Assoc 142: 1390-4.

17. Fenlon DR, Logue DN, Gunn J, Wilson J (1995) A study of mastitis bacteria and herd management practices to identify their relationship to high somatic cell counts in bulk tank milk. Br Vet J 151: 17-25.

18. Meiri-Bendek I, Lipkin E, Friedmann A, Leitner G, Saran A, et al. (2002) A PCR-based method for the detection of Streptococcus agalactiae in milk. J Dairy Sci 85: 1717-23.

19. Boss R, Naskova J, Steiner A, Graber HU (2011) Mastitis diagnostics: quantitative PCR for Staphylococcus aureus genotype B in bulk tank milk. J Dairy Sci 94: $128-37$

20. Lampel KA, Orlandi PA, Kornegay L (2000) Improved template preparation for PCR-based assays for detection of food-borne bacterial pathogens. Appl Environ Microbiol 66: 4539-42.

21. Tilsala-Timisjärvi A, Alatossava T (2004) Rapid DNA preparation from milk and dairy process samples for the detection of bacteria by PCR. Food Microbiol 21: $365-8$.

22. Middleton JR Update on contagious mastitis: Staphylococcus aureus and Streptococcus agalactiae. Natl Mastit Counc Reg Meet August 4-6, 2014, Ghent, Belgium.

23. Mackie D, Logan E (2002) Increased incidence of Streptococcus agalactiae. Vet Rec 150: 555.

24. Edmondson PW (2002) Increased incidence of Streptococcus agalactiae. Vet Rec 150: 554-5.

25. Passchyn P, Piepers S, De Meulemeester L, Boyen F, Haesebrouck F, et al. (2012) Between-herd prevalence of Mycoplasma bovis in bulk milk in Flanders, Belgium. Res Vet Sci 92: 219-20.

26. Tenhagen BA, Köster G, Wallmann J, Heuwieser W (2006) Prevalence of mastitis pathogens and their resistance against antimicrobial agents in dairy cows in Brandenburg, Germany. J Dairy Sci 89: 2542-51. 


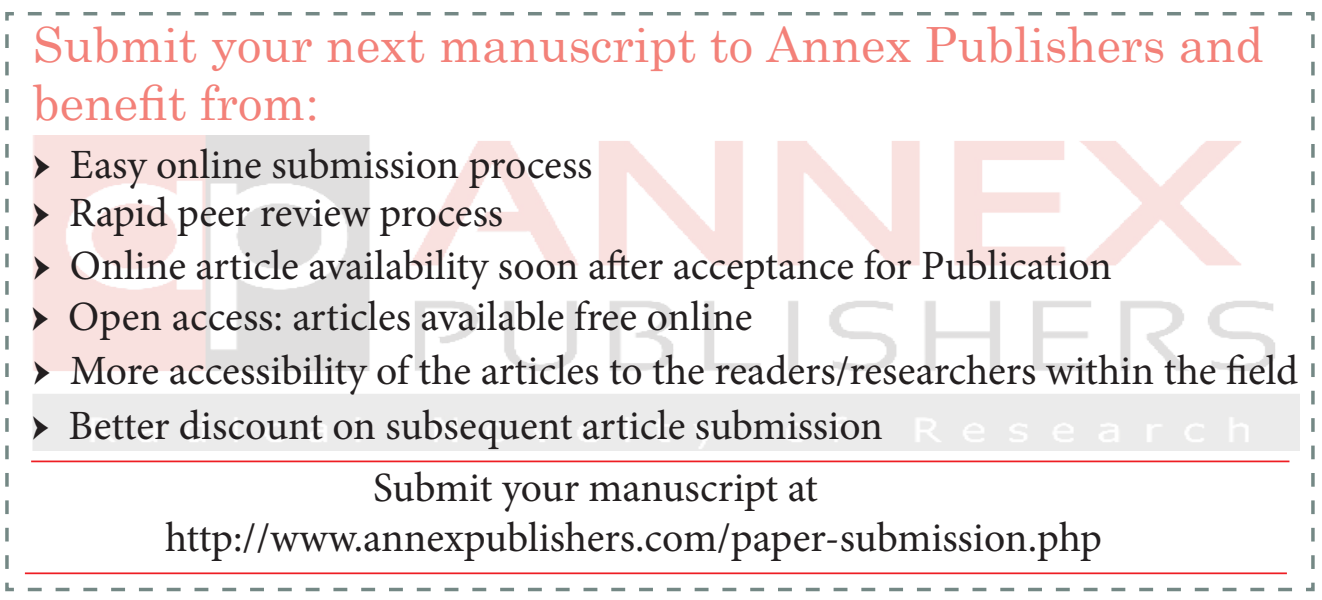

